\title{
DEL OTOÑO DEL GONGORISMO: AGUSTIN DE SALAZAR Y TORRES
}

Muchos son los seguidores de Góngora, fervorosos o solapados, pero pocos los que han aportado alguna nota personal al estilo del maestro. Los más se han limitado a una ceñida imitación sin criba, acentuando, eso sí, las peculiaridades del modelo. Y, sin embargo, estos poetas tienen también su interés, a veces por ciertos aspectos de su obra, por algún hallazgo poético que no merece quedar en el olvido; otras, quizá la mayoría de las veces, como fenómeno literario-social, manifestación de una moda absorbente que invade todo el siglo xvir peninsular y penetra profundamente en el xviII.

Sobre Góngora poseemos magníficos y definitivos estudios; sobre los gongoristas, salvo alguna que otra monografía acerca de algún poeta, no existe casi nada, y ya va siendo hora de ir pensando, en este cuarto centenario del nacimiento de don $\mathrm{L}$ uis, en hacer el balance del gongorismo. Es preciso saber a qué atenernos, sin vaguedades ni idealismos, sobre lá verdadera extensión espacial y temporal del gongorismo, la calidad y cantidad de sus cultivadores, grupos, subgrupos y variantes que ofrece a lo largo de ese hipotético siglo y medio que todos aceptamos como duración de la influencia directa e indirecta de la obra de Góngora.

Claro está que esto, y otras muchas más cosas, no es posible en el estado actual de la cuestión, barajando los mismos nombres de siempre o fijándonos sólo en las grandes figuras, quiero decir, en los segundones de1 gongorismo; es preciso acudir también a las de tercero y cuarto rango. Cuando se haya hecho esto, es decir, se multipliquen las monografías $\mathrm{y}$ estudios sobre esos pequeños amanuenses del Parnaso, que tantas sorpresas deparan a veces, y sobre el éxito de ciertos temas y determinados recursos estilísticos, entonces habrá llegado el momento de levantar el atestado pertinente y mostrar por qué cauces, torrentes o venillas de agua, ha discurrido el gongorismo hasta su consunción final. El ensayo que sigue sobre un casi olvidado poeta del siglo xvIr es una pequeña 
aportación a ese futuro estudio de la difusión de la obra de Góngora y su imitación en la poesía española.

Del raudal de seguidores de Góngora separo, para esta ocasión, a don Agustín de Salazar y Torres, un poeta que apenas si ha merecido la atención de la crítica y que florece en la segunda mitad del siglo xvm, cuando el gongorismo, en un otoño todavía dorado y tenazmente persistente, se desvía, en parte, de la ruta trazada por el autor de las Soledades, para seguir por la que le abre, con delirante pompa barroca, el gongorista Calderón de la Barca en sus tramoyas mitológicas, caballerescas y cortesanas.

¿Quién era Agustín de Salazar y Torres? Su anigo y editor, don Juan de Vera Tassis y Villarroel, en el Discurso de la vida y escritos de don Agustin de Salazar, que publicó al frente de sus obras, traza la primera biografía de nuestro poeta, encomiástica y sin crítica, como propia de "su mayor amigo" y de la época, y que aquí se completa y rectifica, en la medida de lo posible, con nuevos datos de distintas procedencias.

Fue Salazar de ilustre linaje, hijo de don Juan de Salazar y Bolea y de doña Petronila de Torres y Montalvo; nació en Soria, según Vera Tassis, el 28 de agosto de I642, lugar que rectifica Gaspar Agustín de Lara, también amigo de Salazar y Torres, asegurando que éste vio la luz primera en la ilustre y antiquísima villa de Almazán, de donde también era natusal su tío y protector don Marcos de Torres y Rueda, obispo de Yucatán ${ }^{1}$. Infiere el bueno de Vera Tassis, del claro y vehemente ingenio de Agustín, de sus amables costumbres y de su corta vida y fama póstuma, que «rayaría el ángulo de su oróscopo la mediación del Signo de Géminis, con la assistencia del planeta Mercurio, libre de combustión».

Dejemos a Vera Tassis con sus astrologías y sigamos a Salazar y Torres cruzando el Atlántico a los tres años de edad en compañía de su venerable tío ${ }^{2}$, que se lo llevaría a tierras mejicanas con la buena intención de encarrilarlo por la vía eclesiástica o de encontrarle allí cualquier otro buen acomodo. Don Marcos de Torres fue nombrado después virrey de Méjico, en cuyo cargo duró desde el r3 de mayo de r648 al 22 de abril de I649, fecha en que murió.

1 Prólogo a su Obelisco Fúnebre, Pyramide Funesto que construia a la Inmortal memoria de $D$. Pedro Calderón de la Barca. Madrid, r684.

2 Vera Tassis, y con él todos los que le han copiado, dice que Agustín pasó a Méjico a los cinco años, esto es, en 1647. Ahora bien, don Marcos de Torres y Rueda, en cuya compañia fue Agustín, había sido nombrado obispo de Yucatán en I644 y pasó a su residencia en I645, según afirma GIL GoNZÁLEZ DÁvILA, que debía estar más enterado que Vera, en su Teatro Eclesiástico de la primitiva Iglesia de las Indias Occidentales, t. I, Madrid, 1644, pág. 219. 
¿Cuál sería la situación de Agustín al morir su tío, niño de siete años, en país desconocido y lejos de la familia? Parece ser que Salazar habia comenzado sus estudios de letras y artes en el colegio de San Ildefonso, que continuó ventajosamente, iniciándose al mismo tiempo en el cultivo de la poesía, que muy pronto iba a hacerle famoso en los medios literarios mejicanos. Dice Vera que Agustín destacó en seguida por su ingenio, inventiva y sorprendente memoria, y, como ejemplo, cuenta que, aun no cumplidos los doce años, recitó «las Soledades y Polifemo de nuestro Culto Conceptuoso Cordovés», en el colegio de la Compañía de Jesús, "comentando los más obscuros Lugares, desatando las más intricadas dudas y respondiendo a los más sutiles argumentos que le proponían los que muchos años se avían exercitado en su inteligencia y lectura». ¡Pobre niño! Es de imaginar el asombro del auditorio de Salazar ante su precoz ingenio, asombro que años más tarde despertaría de nuevo otra precoz criatura, Juana de Asbaje, no ajena del todo a la influencia de la poesía de nuestro Salazar y Torres. ¿Sería el clima mejicano el que maduraba frutos tan tempranos?

Por entonces llegó a Méjico don Francisco Fernández de la Cueva, duque de Alburquerque, nombrado virrey de Nueva España, de cuyo cargo se posesionó el I $_{5}$ de agosto de I653. Salazar y Torres, a punto de cumplir once años, celebró el acontecimiento en una Descripción en verso de la entrada en México del virrey Alburquerque, México, $1653^{1}$, que posiblemente le abrió las puertas del palacio virreinal, donde el duque mantuvo una academia literaria durante el tiempo de su gestión en aquellas tierras. En ella debió lucirse ampliamente Salazar, en lecturas y discusiones, ganándose la simpatía de los duques y su protección, que duraría hasta su muerte.

En r654, la Universidad de Méjico celebró un certamen poético dedicado a la Inmaculada Concepción, en el que intervino Salazar y Torres en competencia con otros poetas de edad madura, presentando unas "vayas» al diablo, en redondillas de pie quebrado, y un romance, no incluidos en sus obras, que le valieron el primer lugar del certamen y el título de «segundo Anastasio Pantaleón de nuestros tiempos» ${ }^{2}$.

Entre certámenes, competiciones y demás exhibiciones poéticas,

1 Jost Toribio Medina, La imprenta en México. Epitome (I539-1810). Sevilla, I893, pág. 23 I.

2 Certamen Poético que celebró la docta y lucida Escuela de los Estudiantes de la $R$. Universidad... a la Inmaculada Concepción, Méjico, 1654. Vid. Alponso Mendez Prancarte. Poetas Novohispanos. t. II, Méjico, 1943, págs. XLVIIXLVIII. 
Salazar y Torres terminó sus estudios de Teología y Leyes, completándolos, según Vera Tassis, con los de, extraña conjunción, Astrología.

E1 virrey Alburquerque dio fin a su misión en Méjico el I6 de septiembre de 1660 y aquel mismo año emprendió el regreso a España, trayéndose en su compañía al joven Salazar, que iba a iniciar una nueva etapa de su vida.

Ya en Madrid, la protección del duque le facilitó la entrada en la Corte, donde consolidó la fama de estudioso y poeta que había adquirido en Méjico. Fue entonces cuando, bajo el magisterio calderoniano, comenzó a escribir sus comedias para ser representadas en Palacio en las fiestas de cumpleaños de las reales personas, o para regocijo de sus protectores los de Alburquerque o de cualquier otro aristócrata.

Casó, en I666, con una dama cordobesa, doña Mariana Fernández de los Cobos, y el 28 de abril de ese mismo año salía para Denia en el séquito del duque de Alburquerque, que había sido nombrado mayordomo mayor y jefe de jornada para acompañar a la hija de Felipe IV, Margarita María, en su viaje a Austria, para reunirse con su esposo el emperador Leopoldo I, con quien acababa de casarse por poder. Con tal motivo, Salazar y Torres compuso, entre otras poesías, La jornada de la señora Emperatriz de Alemania y un Epitalamio a sus Reales Bodas, inéditos.

De Denia pasaron a Barcelona y de aquí a Finale, Italia, en cuyo puerto desembarcaron el 20 de agosto, siguiendo por tierra hasta Rovereto, donde la emperatriz fue recibida por los representantes de Leopoldo, terminando así la misión del duque. Este, acompañado siempre de Salazar, marchó desde allí a ocupar el virreinato de Sicilia. Alburquerque nombró a Agustín sargento mayor de la provincia de Agrigento y, poco después, su capitán de armas.

La gestión del duque duró de $x 667$ a r670. Eñn este año, ¿o antes?, regresó Salazar a Madrid, donde siguió mostrando su ingenio, admirado por unos y envidiado por otros, que se regocijarían de las desdichas que le aquejaban, pues, dice Vera, «también fue don Agustín en su corta vida desposeído de los bienes temporales", lo cual hace pensar que, a pesar de la protección del duque de Alburquerque, no debió llevar una vida muy desahogada.

Ella, sin embargo, duró poco: una larga enfermedad, que lo dejó "extenuado y atrófico», lo llevó al sepulcro el 29 de noviembre de 1675 , a los treinta y tres años de su nacimiento. En sus últimos momentos le asistió su amigo fray Jerónimo Pérez de la Morena, clérigo regular agonizante. E1 otro, Vera Tassis, compuso por entonces, o quizá en I68I, para la publicación de las obras del poeta, a cuyo frente figura, una hueca canción fúnebre, Fama Posthuma y Eterna de don Agustin de Salazar y 
Torres. Sobre "este cisne del Duero caudaloso", como le llama, vierte Vera el cuerno de la Copia de sus elogios, atribuyéndole gratuitamente las cualidades de un buen golpe de poetas nacionales y extranjeros. Retengamos de esas cualidades "lo culto y lo elegante» de Góngora, «lo agudo» de Quevedo, "la idea y lo ingenioso» de Calderón, y aun los nombres de Pantaleón y Zárate; el resto es bambolla y música celestial:

Formó Don Agustín nuevo Parnaso

en su capaz gloriosa Poesía;

pues de Herrera alcançó la melodía, con la erudita locución del Taso;

lo lyrico, de Lope y Garcilaso;

de Góngora, lo culto y lo elegante;

de Quevedo, lo agudo y lo picante;

de Virgilio, lo heroyco y lo elevado;

de Marcial, lo juizioso y lo salado;

de Petrarca, lo sabio y lo eminente;

de Ovidio, la inventiva y lo eloquente;

del Camoens, lo dulce y lo amoroso;

de Calderón, la idea y lo ingenioso;

de Marino, lo docto y lo suave;

de Argensola y de Zárate, lo grave;

de Lucano, la frassi y la sentencia;

del Dante, la facundia y la eloquencia;

de Pantaleón y Hortensio, lo divino;

porque el todo de todos fue Augustino.

Aparte la edición suelta de alguna pieza dramática o su inclusión en la colección de Comedias escogidas, son dos las ediciones de las obras de Agustín de Salazar y Torres, publicadas, gracias a los desvelos de "su mayor amigo" Juan de Vera Tassis y Villarroel, con el título de Cythara de A polo. La primera edición se publicó en Madrid, en r68r, dedicada a la regente doña Mariana de Austria ${ }^{1}$, con una elogiosa Aprobación de don Pedro Calderón de la Barca ${ }^{2}$ y las consabidas composiciones laudatorias,

1 Cythara/de Apolo,/Varias Poesias/Divinas, y Humanas,/que escrivió/D. Agustin de Salazar y Torres;/ y saca a luz/ D. Iuan de Vera Tasis y Villarroel,/ su mayor amigo:/ ofreciéndolas/a la Cathólica Magestad/ de Doña Mariana de Austria $N^{\text {a }} S^{\text {a/ }}$ A ugusta Reina Madre,/ por mano/del Excelentíssimo Señor/D. Antonio Sebastián de Toledo,/ Marqués de Mancera,/ Señor de las Cinco Villas, \&c./ Primera parte./ Con privilegio,/ En Madrid: A costa de Francisco Sanz, Impressor del/ Reyno y Portero de Cámara de su Magestad. Año I68I./ Véndese en su Imprenta, en la Plazuela de la calle de la Paz. $4 .^{\circ} 25$ h. s. f. +306 págs. +6 h. s. $n$.

2 Dice CAI,DERón que en las obras de Salazar y Torres ha hallado "no sólo quanto imaginava prometido, pero mucho más de lo que esperava imaginados. assí en lo grave de sus heroycos metros, lo dulce de los lyricos, lo apacible de los: jocosos $\mathrm{y}$, finalmente, lo ingenioso de sus inventivas». $\mathrm{Y}$ un poco más adelante las califica de "pulido Tesoro de la lengua Castellana". 
una en francés, entre las que no faltan las dedicadas en loor del propio Vera ${ }^{1}$.

Aunque hasta nosotros sólo ha llegado la Primera parte de esta edición, comprensiva de las poesías líricas y de dos loas y cinco bailes, es posible que por la misma fecha apareciese también la Segunda parte, que sólo se conserva en segunda edición y que comprende nueve comedias; ocho, con sus respectivas loas. La segunda edición, dedicada ahora a don Isidoro de Burgos Montilla y Bárcena, se publicó también en Madrid, en I694 ${ }^{2}$.

Esta segunda edición, al menos en lo que a la Primera parte se refiere, reproduce el mismo contenido de la primera edición, pese a la promesa que Vera Tassis había hecho en una "Advertencia al que aquí llegare", donde, después de explicar cómo recopiló las obras de su admirado y llorado amigo, trasladándolas de los borradores en que aquél las había dejado, lamenta la desvergüenza de quienes se han apropiado obras de Salazar, publicándolas como propias, y promete, para una segunda impresión, sacar a luz las que «ahora», I68I, permanecen inéditas, dando una lista de ellas ${ }^{3}$. De esta lista sólo se publicó una obra en la Cythara, segunda parte: La Loa de la comedia de Thetis y Peleo.

1 Los autores son: D. Félix de Lucio Espinosa y Malo, P. Nicolás García de Londoño, P. Gerónimo Pérez de la Morena, D. Alonso Antonio Altamirano, D. Pedro de Arce, "Belisa, canora eloquente Musa del Mançanares», D. Francisco González de Bustos, D. Pedto Pablo Billet, parisiense, D. Francisco de Atayde y Sotomayor, D. Francisco Saenz de Lezcano, D. Manuel Ordóñez de la Puente, D. Melchor Fernández de León y Gaspar Agustín de Lara.

2 Cythara/de Apolo,/ Varias Poesias/ Divinas, y Humanas,/ Dedicadas/ a Don Ysidoro de Burgos/ Mantilla y Bárcena, \&c/ Primera Parte./ Con Licencia:/ En Madrid: Por Antonio Gonçalez de Reyes. Año/ de I694./ A costa de Alonso Montenegro, y Joseph Bascones Ayo, Mer-l caderes de Libros. Véndese en las Gradas de $S$. Felipe. $4 .^{\circ} \mathrm{e}$ igual paginación que la $1 .^{\mathrm{a}} \mathrm{ed}$.

Cythava/ de Apolo,/Loas y Comedias/ diferentes,/ que escrivió/ Don Agustin de Salazar y Torres, / y saca a luz/ D. Juan de Vera Tasis y Villarroel,/ su mayor amigo./ Dedicadas/ a Don Isidoro de Burgos,/ Mantilla y Bárcena, \&c./ Segunda parte./ Con Licencia:/ En Madrid: Por Antonio Gonçalez de Reyes./ Año de I694./ A costa de Alonso Montenegro, y Joseph Bascones Ayo, Mer-l caderes de Libros. Véndese en las Gradas de S. Felipe. $44^{\circ}$, I h. s. n. + 424 págs.

3 «La Jornada de la señora Emperatriz de Alemania, con el Epitalamio a sus Reales Bodas".

"Dos Autos Sacramentales y una Comedia Burlesca".

"Aun más de una Jornada de la Comedia de Minos y Britomartisn.

"Un Tratado que intitula Espejo de la Hermosura".

"Dos Fábulas Jocoserias, una en Octavas y otra en un Romance".

"Los Metamorfoseos Mexicanos, a imitación de los de Ovidio".

"La Loa de la Comedia de Thetis y Peleo". 
Pero ¿hasta dónde podemos creer en las palabras de Vera Tassis cuando se queja de los que han publicado como propias obras de Salazar y Torres? Porque es el caso, y en verdad que asombroso, que nuestro Vera publicó como de Salazar una obra importante que, sin ninguna duda, no le pertenece. ¿Por qué camino, por qué arte o ciencia, se le pudo ocurrir a Vera atribuir y publicar a nombre de Agustín de Salazar y Torres la fábula de Orfeo de Juan de Jáuregui? ¿Acaso tenía aquél una copia entre sus papeles e ignorando Vera, y ya es ignorar en hombre de letras como él, la existencia del poema de Jáuregui, publicado en I624, lo creyó original de su amigo? Sea como fuere, el Orfeo se imprimió a nombre de Salazar en la Primera parte de la Cythara de Apolo, páginas I72-220, con el título de Fábula de Eurídice y Orpheo y sin otras diferencias, aparte el título, que una primera octava no existente en Jáuregui ${ }^{1}$ y algunas variantes de escasísima importancia, limitadas las más de las veces al cambio de una palabra ${ }^{2}$.

Esto hace pensar si el resto de las obras, poesía y teatro, publicadas a nombre de Salazar y Torres, le pertenece en su totalidad y en qué grado penetraron en ellas las pecadoras manos de Vera Tassis en su deseo de enmendar y pulir los manuscritos de su entrañable amigo. Sobre esto

"Tres Bayles, sin algunas Traducciones de Poetas Griegos y Latinos, (a) con otras Poesías diferentes, Sacras, Heroycas, Lyricas, Amorosas y Burlescas».

(a) En la Cythara de Apolo se publican quince traducciones breves de varios poetas, entre ellos Anacreonte, Ausonio, Sannazaro y Poliziano. que con métrico impulso sonoroso herirá el destemplado plectro mío, pues pudo su dulcissímo instrumento imponer yugo al Mar, coyunda al Viento.

2 Compárense las dos primeras octavas en la edición de 1624 y en la de Vera Tassis:

Gozava juvenil del Trace Orfeo de libre edad la primavera ociosa, dando a sus años regalado empleo la lira dulcemente numerosa: no el vinculo legal del Himeneo afectos cede, ni a la Cipria Diosa, qual si anteviera el ánimo presago ya por su medio el venidero estrago.

(1624.)
Lograva en juventud florida Orpheo de libre edad la Primavera ociosa, dando a sus años deleitable empleo la lyra dulcemente numerosa: no al vínculo legal del Hỳmeneo afectos cede, ni a la Cypria Diosa, pues en tranquilo afecto regalado, su música es su amor y su cuidado.

(Cythara.) 
tiltimo sabemos que concluyó un poema, el de las Estaciones del dia, y una comedia, El encanto es la hermosura, que Salazar dejó sin terminar, y escribió los actos segundo y tercero de otra no recogida en la Cythara, Más triunfa el Amor rendido, de la que Salazar había escrito el primero. Pero ¿y el resto? Porque en cuanto a que sea de Salazar el resto de la Cythara, tenemos la denuncia de Gaspar Agustín de Lara, que, en el Prólogo de su citado Obelisco Fúnebre, afirma que, además del Orfeo, no pertenecen a Salazar varias poesías y una comedia, sin que dé títulos de unas y otra ${ }^{1}$. Hasta qué punto sea cierto esto, es dificil afirmarlo; por tanto, descontados los casos citados, consideremos, por el momento, como obras de Salazar y Torres todas las publicadas en los dos volúmenes de la Cythara de Apolo.

Poesia.

Agustin de Salazar y Torres no es, por supuesto, un gran poeta, ni siquiera un poeta original en la medida que lo son otras figuras secundarias de la época, pero, a veces, intenta caminar por sus propios medios y consigue salir adelante con la suficiente soltura, para que no lo consideremos inferior a esos otros poetas que suelen citar siempre las historias literarias cuando se trata de gongorismo. Méndez Plancarte lo elogia quizá demasiado y se indigna del olvido en que yace o de los juicios negativos o tibios de que ha sido objeto. Tal vez por eso y por considerarlo mexicano por su domicilio y su educación» intenta reivindicarlo, creo que sin razón, para aquellas tierras, diciendo que "al tornarlo a México lo hacemos tanto más gustosos y seguros, cuanto que el general despego de los críticos y antólogos peninsulares parecería (como en el caso de Palafox y otros) renunciar a su parte en esa gloria»"

Sin intentar polemizar, está claro que es inadmisible una tal actitud, que nos llevaría a la mayor confusión si comenzásemos a aplicar a otros

1 "Tampoco penetro el aver atribuido a Don Augustín obras que tan manifiestamente se sabe que no son suyas, como es la Fábula de Orpheo, de Don Juan de Jáuregui (impressa tantos años ha), la Comedia de Don Juan Cuero de Tapia, Cavallero de el Abito de Santiago y Regidor más antiguo desta Corte (que yo he visto en sus borradores) y otras Poesias de otros muchos Ingenios que oy viven; porque aunque las obras de estos reconocen por grandes a las de Don Augustín, no querrán parecerlo reguladas por ellas, sino por si propias, quando no pueden, aunque sean grandes, engrandecer a las que por si mesmas se han engrandecido." Véase lo que dice LA Barrera, Catálogo del Teatro Antiguo Español, s. v. Cuero y Tapia y Salazar y Torres.

2 A. Mández Plancarte, Poetas Novohispanos. II. México, 1943, pág. LIX. 
autores. Por lo que al nuestro se refiere, ahi tenemos ya el fruto en E. Anderson Imbert, por citar un ejemplo reciente, que en su Historia de la Literatura Hispanoamericana, 2.a ed., México, 1957, cita ya a Salazar y Torres como "gongorista mexicano".

Poeta español, y bien uncido al carro gongorista como sus compañeros de fatigas poéticas, Salazar y Torres barajó con destreza los tópicos de la poesía barroca en géneros, temas y recursos expresivos. Sobre su parva, aunque no despreciable aportación personal, se acumulan todos los elementos de la obra gongorina: léxico, cultismos sintácticos (hipérbaton, ablativos absolutos, verbo ser con el sentido de 'servir' o 'causar'), trueque de atributos, fórmulas estilísticas del tipo $A$, si no $B$, metáforas e imágenes, alusiones y perifrasis, etc., que creo inutil señalar, porque cualquier lector de Góngora puede identificar fácilmente.

\section{Versificación.}

Cultivó Salazar variedad de versos y estrofas, en consonancia con los gustos de su tiempo. En la Primera parte de la Cythara de Apolo, en la que se recoge toda su producción lírica, la proporción de endecasílabos y versos cortos (trisílabo, tetrasílabo, hexasílabo, heptasílabo, octosílabo, con predominio de este último), es casi la misma, si bien hay mayor número de composiciones en versos cortos.

En las formas métricas italianas, los tipos estróficos más cultivados son el soneto y la silva, aunque también utilizó la lira en sus dos variantes de cinco $y$ seis versos.

En los versos cortos predominan el romance y las décimas, pero tamvién cultivó la redondilla, la endecha, la seguidilla, la quintilla y las coplas con distintas combinaciones métricas.

L,os romances se sujetan, en general, al tipo predominante en el siglo XVIr, esto es, con los versos ordenados en cuartetas y a veces con estribillo; hay, además, uno heroico (pág. 38), otro decasílabo con esdrújulo inicial (pág. I28) y dos con el cuarto verso de cada cuarteta endecasílabo (páginas II8 y I5I), semejante a las endechas reales, de las que hay cuatro ejemplos en la Cythara (págs. I3I, I34, I55 y 228).

Las coplas ofrecen bastante variedad. Muy joven aún, ensayó las coplas manriqueñas en unas dedicadas a la duquesa de Alburquerque, siendo virreina de Méjico: 


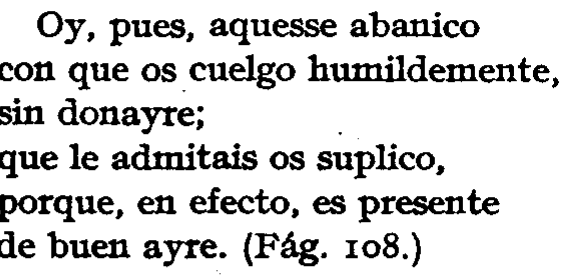

Escribió coplas que adoptan la forma de romance, seguidilla o redondilla con estribillo, en algún caso bastante extenso, y con una «introducción" igualmente en verso. Los estribillos suelen ser amétricos, para cantar, como las coplas, a una, dos y hasta tres voces. Otras veces la copla presenta una estructura más complicada, reuniéndose en ella distintos tipos estróficos, como, por ejemplo, en la siguiente combinación de redondilla, pareado y seguidilla:

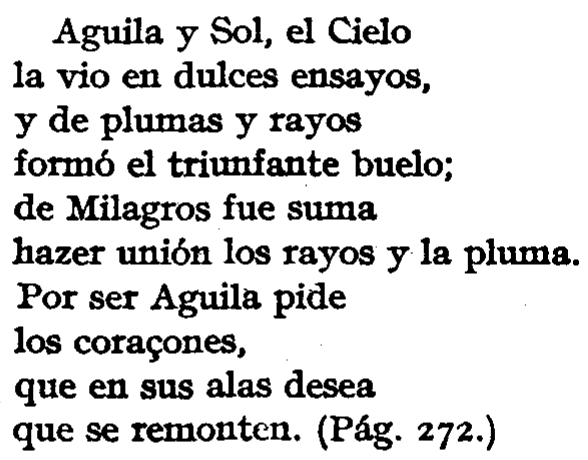

No abusó Salazar, a pesar de la vecindad calderoniana, de los artificios de plurimembración y correlación, aunque no sea difícil espigar muestras en su obra lírica y, por supuesto, en la dramática, tan emparentada con la de Calderón.

Me parece ocioso dar ejemplos de bimembres, utilizados según el mom delo gongorino, o de otros plurimembres, que suelen aparecer un poco perdidos en el interior del poema. Me limito sólo, por curiosidad, a ofrecer un ejemplo de diseminación con recolección interior y nueva diseminación, en la que flor = clavel: se trata del estribillo de unas coplas "A una dama que tenía en el pelo un claveln:

En el pelo divino de Clori se oculta un enigma, que adoro fiel; descifralo, Amor, pues te escondes en él: Brillar púrpura le vi: ¿es Rubi? 
No, que fue su luz más bella.

¿Es Estrella?

No, que es ámbares su olor.

¿Será flor?

Ni es Flor, ni Rubi, ni Eistrella,

padeces error,

porque todo lo es:

Rubi con fragrancia,

Estrella con hojas,

con luzes Clavel. (Pág. 164) 1 .

Temas.

La poesía de Salazar y Torres es académica, quiero decir, de Academia literaria, como debió serlo, en su mayor parte, la poesía española del siglo xvir. Aquellas reuniones, que alguien llamó de ociosos, desempeñaron un importante papel social y literario, $y$, en este último aspecto, son el equivalente de las revistas poéticas de nuestros días, en lo bueno y, sobre todo, en lo malo. Nacida, en gran parte, por no decir en su totalidad, del pie forzado de unos temas propuestos con anticipación, esta poesía, por fría e insincera, carece de calor humano y afectividad y sólo puede salvarla su logro formal o, en ciertos casos, la carga afectiva con que, por un determinado estado de ánimo personal queramos enriquecerla.

En el caso de Agustín de Salazar esto es tan claro y evidente que el mismo poeta, o su colector, se encargó de decírnoslo en las rúbricas de sus poesías, en muchas de las cuales se aclara que ufue assumpto de Academian, y, cuando no, se adivina. La primera Academia en que actuó Salazar debió ser la que acogía en sus salones virreinales de Méjico el duque de Alburquerque; después, en Madrid, también debió de frecuentar alguna y hasta presidirla, como indica la Oración que escribió siendo Presidente de una Academia (págs. 24-33), esmaltada de lugares comunes.

Poeta cortesano y proveedor de comedias para fiestas reales, Salazar festejó bodas aristocráticas, cumpleaños, viajes y salidas. Eñ cierta ocasión dedica un romance a la duquesa de Alburquerque con motivo de haberse quitado un luto que traía; en otra, al pobre Carlos II, en la primera salida que hizo en compañía de su madre, doña Mariana de Austria, en cuyo cumpleaños le llama "Reina de las Aves»; en otra ocasión son las bodas de un hijo del Almirante de Castilla o las del duque de Veragua, a quien dedica un romance endecasílabo no carente de elegancia y armonía:

1 Otro ejemplo de diseminación y recolección interior e imperfecta, en el soneto Junto a una dulce fuente que sonora, Cythara, pág. 66. 
Dónde apresuras la dorada pluma? ¿Qué Región busca el dilatado buelo? ¿A qué conduces tantos esplendores, Sacra Llama Deidad y Dios Incendio? ¿Qué nueva hermosa tropa de Cupidos sigue tus alas y en pintados cercos, animado esquadrón de Mariposas, corona a tornos el sagrado fuego? $¿ Q u e ́$ guirnaldas esparce, que, confuso con Flores, con Estrellas, dada el viento si acaso brillan luzes los Claveles, si acaso exhalan ámbar los Luzeros? ¿Qué lluvia de Jazmines y de Rosas el Ayre haze pensil, tanto, que el suelo admira como extraños sus matizes viendo al Abril que muda de elemento? ¿Adónde armaste las doradas flechas de tan suave dolor, dulce veneno, que anhela el coraçón por ser herido y ya es solicitud lo que antes miedo? $¿ Q u e ́$ se hizieron las vendas que antes eran de la purpúrea vista impectimento? ¿El lazo quitas y los ojos abres? Sin duda el tiro dize grande acierto. (Págs. 38-39.

$Y$ asf sigue hasta un total de 124 versos.

a) Amor.

Ia poesía amorosa ocupa un lugar importante en la producción poética de Salazar, aunque, bien entendido, se trata, como ocurre en tantos poetas de su tiempo -en los de todos los tiempos también-, de retóricos galanteos cortesanos o académicos, en los que las Marfisas, Lisis, Cintias, Cloris y Anardas no son quizá más que bellos nombres femeninos, objeto de dulces reproches o amargos requiebros, en los que, a veces, se escucha un vago eco de cancionero cuatrocentista, como en las coplas en que defiende - recuérdese el debate sobre el "cuidar" y el "suspirar" -que es más fineza explicar su amor que tenerlo oculto (pág. I52), o como en un romance en que Alienta a su coraçon a que explique el dolor que he aflige:

1 He alterado algunas interrogaciones que creo equivocadas en el texto. 
Coraçón cobarde mío, explica más tu dolor, que no es razón que le ocultes, si le sientes con razón.

¿De qué te sirve el silencio si no alivias el dolor?

[Y quando el premio te falta, ¿đe qué el silencio sirvió?, etc. (Pág. I40.)

Pero lo que sobre todo abundan son esas galanterías triviales recamadas de flores y de argentería y colorismo culterano. En una ocasión el poeta dedica un romance $A$ un lazo encarnado que tenía Clori en el pie:

Sin duda el lazo de nácar, que prisión hermosa es del breve y bello jazmin que se adora y no se ve, venda de Amor fue primero, porque el dios quiso poner lo que fue adorno a tus ojos, por tropheo de tus pies, etc. (Pág. I45.)

En otro momento son unas liras las que nos presentan a Fili matando con sus manos a una mariposa que se había aproximado a sus ojos (páginas I30-I) o una endecha real $A$ un palillo de sauce que tenia una Dama en $s u$ boca, que le permite dedicarle alambicadas naderías como las siguientes:

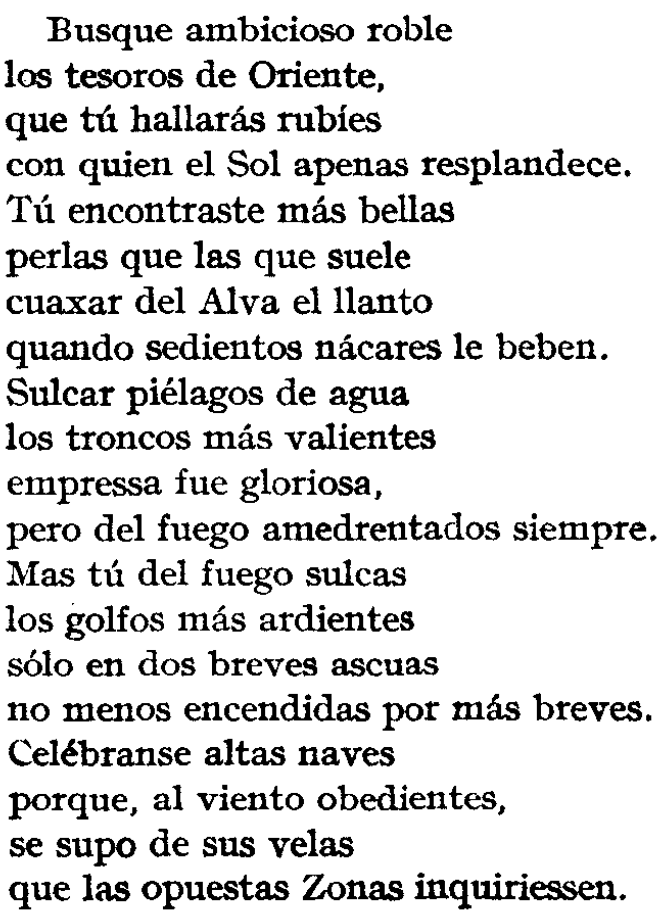




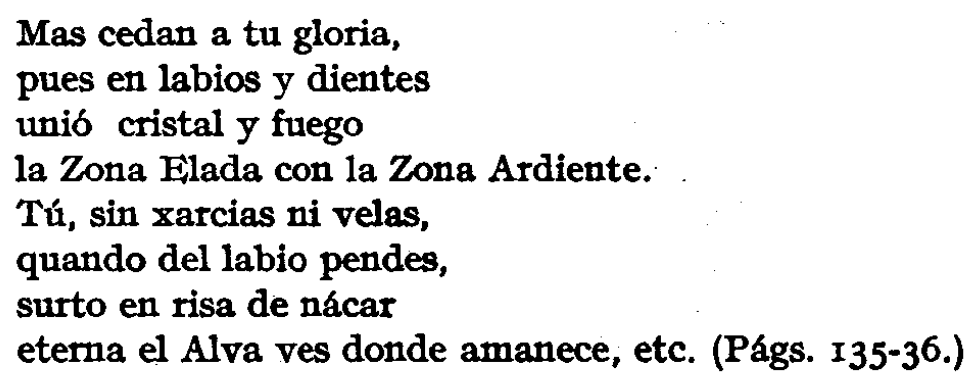

Otro aspecto de estas triviales galanterías son los retratos, tan cultivados en la poesía del siglo xvir y de los cuales la Cythara de Apolo ofrece abundantes ejemplos. El poeta echa mano de todos los tópicos conocidos para describir los encantos de sus Fílidas y Casandras, con los cabellos como "piélagos de azavache" u "oro de la Arabia», con rostros en los que se mezcla nieve y púrpura, $y$, después, todo ese cortejo de jazmines, perlas, claveles, azucenas, cristal y ámbar ${ }^{1}$.

En un romance hace el retrato de una Dama compuesta de varios metros:

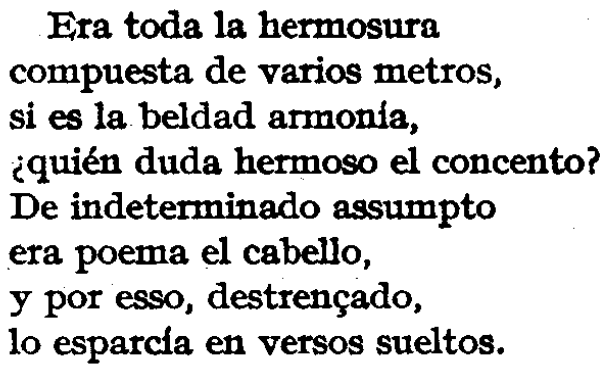

Y sigue con «la nariz, poema heroyco», "églogas sus dos mexillas», "elegía su bocas, "sátira es su mano», etc. (pág. 144). Mientras en otro lugar Pinta la belleza de una Dama en lo conciso desta dézima, con doble correlación trimembre en los cuatro primeros versos:

Son ojos, cejas, cabello, negros, corvas, dilatado, y lisa, breve y nevado, tu frente, nariz y cuello, blancas manos, pecho bello, las mexillas fuego y nieve, los dientes un yelo aleve que incendio en tus labios fue, estrecho el talle, $y$ el pie es, como el retrato, breve. (Pág. I65.)

1 Véanse los romances de las págs. I13, I24, 128, I29, I48, 149, I50 y 159 , las seguidillas de las páginas 129 y 226, y las redondillas de las págs. I05 y 106. 
b) Moralidad del desengaño.

No podía faltar en la obra de Salazar el tema del desengaño, que si, en este caso, no moraliza con ríos y ruinas como ejemplos de fugacidad de vidas y bienes, sí medita ante sepulcros y rosas.

En el soneto funeral $A$ la muerte de un grande héroe (pág. 54) es fácil identificar el parentesco estilistico:

Este que a breve mármor reducido

lágrimas solicita, si no horrores, si a duración atiende, si a esplendores, fue Cometa veloz, fue Sol luzido, etc.

En las liras Tropezó un caminante de noche en un Sepulcro (págs. 22I224) encontramos un característico ejemplo de esa corriente tenebrista -nocturnidades y horrores-, de la que tanto gustaron poetas y prosistas barrocos:

\author{
Pyra horrible y funesta, \\ lúgubre habitación, gruta sombría, \\ estancia que dispuesta \\ estás a ser marmórea esfera fría \\ de la muerte, ¿qué intentas? \\ ¿Qué quieres, que mis ciegos passos cuentas? \\ Funeral aparato \\ de confusión, caverna o laberynto, \\ cuyo rumboso ornato \\ consiste en lo aparente, iqué distinto \\ es tu lóbrego seno, \\ brindando en copa de oro vil veneno!
}

$\mathrm{Y}$ sigue una serie de «noche sombria», «lobreguez», «pálida noche», "madre de oscuridad", "fúnebre assiento", "Imperio de la sombra», "fúnebre teatro de la muerten, etc., con acentos casi románticos.

En cuanto a la rosa, Salazar no parece tomar muy por lo serio el tema, pues, fijémonos bien, no lamenta, sino que, en un soneto, Celebra la brevedad de la vida de la rosa (pág. 53), porque

Este exemplo feliz de la hermosura, que en purpúreos ardores resplandece, si a dar admiraciones amanece, a no dar escarmientos se apresura.

"¿Para qué más edad?", se pregunta Salazar, 
Sobrada eternidad es una hora, para ser en la muerte maravilla y no ser en la vida desengaño ${ }^{1}$.

c) Religión.

Como poeta sacro, Salazar y Torres es una prueba más de lo que significó, en general, este tema en la poesía española del siglo xvir, en que la mayor parte de los poetas que compusieron poesía sacra lo hicieron con escasa emoción y superficial religiosidad, simples jugueteos devotos entre los que puede espigarse algún delicioso villancico. Las poesías divinas" de Salazar son siempre ocasionales, escritas para certámenes o academias, con motivo de un traslado de reliquias, de una fiesta religiosa -la Purísima Concepción, la Natividad, el Santísimo Sacramentoo en loor de algún santo, y son, en lo sacro, lo que son, en lo profano, esas composiciones inefables «a Casandra peinándose", "al lazo de Clori" o "a una dama con un clavel en el pelo".

Al frente de estas poesías, destaca por su hinchada vacuidad un centón en que se Descrive la visión del capitulo doze del Apocalypsi, con sólo versos mayores de D. Luis de Góngora, siguiendo el méthodo de sus «Soledades" (págs. 259-262):

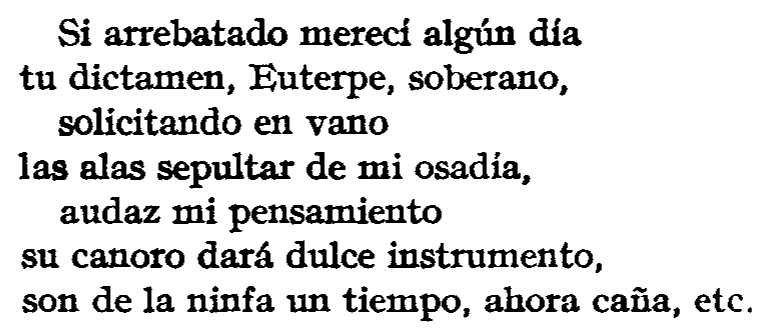

La taracea que «fue assumpto de un Certamen de la Puríssima Concepción de Nuestra Señora se compone de versos, embutidos a veces con ingenio, procedentes de las Soledades, el Polifemo y el Panegírico, además de sonetos y alguna otra composición gongorina ${ }^{2}$.

Tampoco podían faltar, muy en los gustos de la época, los juegos de pa-

1 En otro soneto, pág. 65, hace donaire ucon moralidad de la rosan:

$$
\begin{aligned}
& \text { Rosa del prado, Estrella nacarada, } \\
& \text { astro que el mismo prado ha producido, } \\
& \text { a los soplos del Zéphiro encendido, } \\
& \text { que no pierde la Rosa por soplada. }
\end{aligned}
$$

2 Fue publicado por Gerardo Diego en su Antología Poética en honor de Góngora. Madrid, 1927, págs. I12-116. 
labras irreverentes, como en unas Quintillas de ciego a la gloriosa Santa Catalina de Sena, con ingeniosidades como las que siguen:

Una corona estremada la puso con mil primores toda de espinas formada; pero de aquellos favores dizen que quedó picada.

Dios, de su afecto picado, cinco llagas la imprimió y ella vio su amor pagado, mas de las cinco quedó con un dolor de costado.

Ya de su amor satisfecho el coraçón la trocó y todo de amor deshecho, quando el coraçón la dio, metió la mano en su pecho. (Pág. 304.)

Claro está que éste es el peor aspecto de las "poesías divinas» de Salazar, entre las que también se cuenta alguna con cierta artificiosa gracia rítmica y musical ${ }^{1}$.

d) Mitología.

Gustó nuestro poeta de aludir frecuentemente a mitologías, a veces con bellos aciertos, pero, mientras su teatro ofrece una incontestable predilección por los asuntos mitológicos, en la obra lírica no se encuentran más que dos romances sobre ese tema: uno de Psiques y Cupido y otro de Venus y Adonis. El primero, Pinta al amor dormido en los braços de Psiques y previénela no le despierte, tiene un acentuado tono lírico, propio para cantar, como indica además el estribillo en él introducido.

Enamorado de Psiques, baxa Amor a los vergeles que las campañas del ayre fabrican y desvanecen.

1 Recordemos también, entre tres sonetos de asunto bíblico, el hecho a imitación del Salmo 136, Super flumina Babilonys:

Sobre los ríos, sobre las arenas de Babylonia, el oprimido Hebreo llorava triste, lamentava reo tus memorias, Sion, no sus cadenas, etc. (Pág. $5 \mathrm{I}$.) 
En los braços de la Ninfa, dormido, el ardor suspende, que estando favorecido, no es mucho que se durmiesse.

\section{Estribillo}

Tente, Psiques, espera, no le despiertes, pues que descansa el Mundo, porque Amor duerme: teme, tyrana, teme, que si tú le despiertas, él te desvele.

(Pág. 153.)

El segundo romance, más ambicioso, es la Fábula de Adonis y Venus, dedicada a la duquesa de Alburquerque (pág. I69-I72). Es ésta una de las composiciones más culteranas de Salazar y Torres, que acumuló en ella, como ya indicó José María de Cossío en fino análisis ${ }^{1}$, toda la argentería, cultismos léxicos y sintácticos, alusiones y fórmulas del gongorismo crepuscular.

En I64 versos con rima en $u o ́$-los 24 primeros pertenecen a la declaración del asunto y a la dedicatoria- describe Salazar el escenario donde va a tener lugar el encuentro de Venus y Adonis, la escena de amor y la muerte del joven, todo precipitadamente, pero bien arropado en recamada imaginería, en la que puede comprobarse la procedencia gongorina, cuando no directa, con ecos calderonianos, como en la aparición de la diosa:

Passava Venus a Gnido

a ver desatar su culto, de la thurffera Arabia ostentaciones en humo.

$Y$ viendo la verde Tempe, donde impelida del rudo Invierno, tiene en su sitio la Primavera refugio.

El carro dexa, a la selva claveles creció pupúreos su marfil, en breve engaste de cinco argentados puntos.

Buela el Niño, dulce abeja, a las rosas que produxo rigor Estivo en su rostro, vinculadas a ligustros.

1 Fd́bulas mitologicas en España. Madrid, 1952, pág. 652 y ss. 
$\checkmark$ cayendo aguda flecha

-assi Amor remata el gusto-.

tersa de cristal aljava

halló en el pecho desnudo.

Castigara al hijo Venus, mas cometido el insulto, con remos surcó de pluma mares de viento difusos.

La siguiente cuarteta prepara la entrada del joven cazador, que aparece tocado con un sombrero con plumas, como en el cuadro de Venus y Adonis, de Tiziano, en la Galleria Nazionale de Roma:

Resonó la selva entonces

de venatorios tumultos

$y$ voces infunden alma

en el valle más profundo.

$Y$ sale gallardo Joven,

vibrando venablo agudo,

claro espejo donde Febo

copia su bello trassumpto.

Pululante el bozo, adquiere

respeto de hermoso bulto, sacando en números de oro la suma de quatro lustros.

Ostenta doble coleto, $y$ de Ofir el metal rubio no le permite ser ante entre las franjas oculto.

Portátil de plumas monte era el sombrero, e importuno Zéfiro en blandos embates colores dexa confusos.

Adonis ve a Venus $y$, excitando con la espuela su «fogoso bridón», llega a su lado, salta del caballo y

En la tierra, entonces Cielo, cortés la rodilla puso, y si no el terso alabastro, besarla intenta el coturno.

Levanta al Garçón Idalia

de la blanca mano, y pudo

la calentura de Amor manifestársela el pulso. 


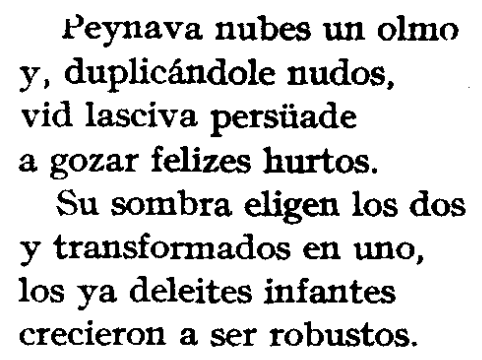

Tras la escena amorosa, se marcha la diosa en su carro tirado por "cándidas aves", mientras Adonis se ve asaltado por el jabalí ("trueno le assalta espumoso-, rayo le fulmina ebúrneou) que lo mata. Entonces,

\author{
Venus, al ¡ay!, retrocede, \\ y en sucessivo diluvio \\ debió el hermoso cadáver \\ mil perlas a dos carbunclos.
}

Con lo que el poema termina casi abruptamente.

Obsérvese que la influencia gongorina no se limita aquí al peculiar uso de términos como 'desatar', 'pululante', 'ya', etc., o a transposiciones del tipo de "portátil de plumas monte", y otras notas por el estilo, sino que hay una consciente imitación de ciertos pasajes del Polifemo. Así, esa "aguda flecha» disparada por el niño dios, que «tersa de cristal aljaba —halló en el pecho desnudon, procede de los vv. 243-44 de la Fábula gongorina: «carcaj de cristal hizo, si no aljaba - su blanco pecho, de un arpón dorado». Y el encuentro de Adonis y Venus, desde ese intento de besar el coturno de la diosa, hasta que ella levanta al joven, para terminar en sus brazos, tecuerda la escena de amor entre Acis y Galatea (vv. 297-336 del Polifemo).

No fue ésta la única vez que Salazar y Torres recurrió al Polifemo gongorino como manantial de inspiración. En la Egloga del Amor (págs. I-8), en la que se introduce "a Cupido enamorado de la milagrosa beldad de Cintian, entona aquél su canto con parecidos acentos a los del Cíclope por la esquiva Galatea:

\author{
¡O Cintia, más süave, más divina \\ que el blanco lylio que nevó la Aurora, \\ quando corriendo al Mar la azul cortina, \\ del Mar sereno la campaña dora ${ }^{1}$ : \\ más bella que el Sol mismo quando infante
}

1 Sobre este comienzo, polifémico procedente de la octava 46 del poema de Góngora ("Oh bella Galatea, más süave / que los claveles que tronchó la aurora»), de la que se ha retenido además la rima «aurora-dora" y se ha transformado en kazul cortina" el "manto azul" gongorino, se superpone una imagen de la Soledad 
en los braços del Alva su luz crece, si primero en tus ojos no amanece, de sus rayos amante, rigiendo tu beldad su Monarquia, luz venerada de la luz del día. (Pág. 4.)

Cupido, a continuación, sin hacer, como Polifemo, un elogio de sus riquezas, sí se alaba de su poder para sujetar corazones y voluntades:

Fueron de poder corto, vil trofeo, quantas Ninfas habitan desdeñosas ya en troncos, ya en cristales, sugetas las han visto mis cadenas; y de mis armas siempre poderosas aun te darán señales duros troncos, estériles arenas: mas para qué te doy tan corta muestra, quando al amago solo de mi diestra se ve ardiendo Neptuno,

Júpiter con amor, con zelos Juno; si esto puedo en los Dioses Celestiales, ¿cómo será el destrozo en los mortales? (Pág. 5.)

Una canción heroica, "assumpto de Academia», en la que el poeta "describe un amanecer, hallando al salir el Sol a Cintia dormida debajo de un jazmín» (págs. 9-ro), descubre su parentesco gongorino desde los primeros versos:

La noche en las espumas sepultada, ahuyentando las nieblas horrorosas, el Aurora salió de blancas rosas y de violas azules coronada ${ }^{1}$; dexó de Tetis la campaña fría, y dividiendo el rosicler del día 2 , afrentados los astros superiores, aun las luzes huyeron como horrores.

Al correr las cortinas carmesíts, los verdes troncos coronó de perlas, desplegando los labios a cogerlas roxos claveles, blancos alhelíes, que ámbares espirando en cada aliento, vida del prado son, alma del viento. (Pág. 9.)

Segunda, vv, 335-336 (đlilios, que en fragrantes copos/ nevó mayo») y un verso del soneto Rayo, dorado Sol, orna y colova, n. ${ }^{\circ} 22 \mathrm{I}$ de la ed. MiLIf́́ ("el mar argenta, las campañas dora").

1 Comp. "De violas coronada / salió la Aurora", vv. 437-438 del romance La ciudad de Babilonia, núm. 74, ed. Milı́́.

2 Un "rosicler del día» en el v. 4 del Polifemo. 
Surge el Sol, iluminando el paisaje:

Sucedió, al fin, el Sol al alva fria, y entre cerúleos velos, el cóncabo dorando de los cielos, de tanto resplandor se formó el dia;

y Cintia aparece dormida, como Galatea en la fuente:

A Cintia ve, que a la quietud hermosa de un blando sueño entrega su hermosura, donde un jazmin, que amante la procura, cortina fue de su Deidad frondosa, planta que supo ser agradecida, pues su nevado pie le dio la vida para tan venturoso atrevimiento, color su frente y suavidad su aliento.

Libre el cabello que prisión ignora, sobre azuzenas dilató espacioso; ya el cuello anega en ondas proceloso, ya con hebras de luz el ayre dora: El breve nácar que al Abril colora, ámbar concede al prado venturoso; y en lo demás del rostro milagroso venció a despierto Sol dormida Aurora. (Pág. Io.)

A la Canción Heroyca sigue un Canto amebeo (págs. 10-24), cuyo «digno sujeto» continúa siendo la hermosa Cintia. Aquí, en una dilatada sucesión de coros, se encuentra el siguiente eco de "el dulce alterno canto" de la Soledad Primera, vv. 767-844:

Ven, ó Cupido, ven, ven, $\delta$ Cupido, ven, ó Cupido, ven, y más que armado de las saetas siempre venenosas;

ven de purpúreas rosas, ven de cándidos lilios coronado; ${ }^{1}$; depón ya los rigores, suspende los ardores que la antorcha fulmina poderosa; míresse alguna vez tu aljava ociosa y el arco suspendido; ven, o Cupido, ven, ven, ó Cupido 2. (Pág. r3.)

1 APurpúreas rosas» y "cándidos lilios» como en los vv. I05-106 del Polifemo.

2 En la jornada primera de La mejor flor de Sicilia, comedia de nuestro autor (Cythara, II, pág. I04), un coro canta como acompañamiento estos dos versos epitalámicos, copia, el segundo, de Góngora:

De amor al mayor trofeo,

ven, Himeneo, ven, ven, Himeneo. 
$\mathbf{Y}$ más adelante, una perifrasis también gongorina:

Ven, ó Cupido, y las azules plumas

ligero entrega al ayre vagaroso;

asiste, pues, ó hermoso

nieto de las Espumas ',

a las glorias de aquélla,

más que tu madre bella. (Fág. 13.)

e) Soledades.

El fervor gongorino de Salazar y Torres le llevó a componer, como ocurrió con algún otro poeta de su tiempo, una Soledad a imitación de las de don Luis de Góngora (págs. 34-38), de $\mathrm{I}_{53}$ versos cargados de toda la pompa metafórica y musical que en los campos soledosos o polifémicos había agavillado don Agustín.

El asunto del poema (amanece y los rayos del sol despiertan a la ninfa Cianes, que, a punto de ser herida por un jabalí, es salvada por un joven: ninfa y salvador se enamoran recíprocamente) es lo de menos. Salazar se valió de tan leve episodio, expuesto en los últimos cuarenta versos del poema, para desplegar su arte culterano, sin más preocupación que encadenar imágenes y derramar cultismos. Y no deja de conseguir algunos buenos efectos, como puede juzgarse por los siguientes ejemplos:

Del blanco Cisne la progenie hermosa

iluminaba el Sol con rayos de oro,

la imagen luminosa

dexando opaca del fingido Toro,

quando del lecho de nevada espuma,

segunda de las ondas Cyterea,

de aljófares bañada,

si no de quanta perla coronada

concha parió Eritrea,

se levantó la Aurora,

por cuya luz primera

tanta la saludó turba canora,

música, digo, pluma

de pintada armonía,

quanta huyó de la nueva luz del dia

multitud luminosa

de la más tachonada ardiente Esphera:

1 Nieto de la espuma" por 'Cupido', en Soledad Segunda, v. 521. 
Destrençó, pues, el Alva la melena, cuyo sacro rocío

en perla vio quaxado, no en concha nacarada, en hoja si de nácar congelada,

Pues los jardines de la fruta de oro, de casta hermosa Nimpha, si ya fiera, dorado estorvo a la veloz carrera ${ }^{1}$, $y$ por cuyo valor se vio afrentada de Júpiter la esposa, gloria mayor de la purpúrea Diosa, bien que en Troya vengada;

... el Meandro...

que coronado de flexible caña -deidad que fugitiva fue algún día-. levantó la cabeça, siempre undosa al sonoro concento, a la armonía de las aves de Apolo, que haziendo su ribera sacro nido, con uno y otro acento,

pretenden, en el verde mauseolo de la grama frondosa, la muerte suavizar con el oído, si no es que, al exhalar la dulce vida, la quexa con las vozes divertida, música pareció lo que es lamento; tantos, pues, ensordecen su ribera, que la más lince vista mal pudiera tantas cándidas plumas apenas distinguir de sus espumas.

Vengada, pues, la Nimpha se levanta y el margen pisó apenas del padre cristalino, dando su pie divino más flores a sus ondas que vio arenas, quando detuvo su ligera planta herido un javali, mas feroz tanto, que aunque bañado de coral inmundo, susto de Venus pudo ser segundo y segundo terror del Erimanto,

1 Comp. Polifemo, vv. I30-r 32:

... ser bien quisiera,

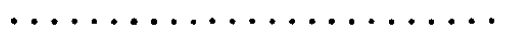

dorado pomo a su veloz carrera. 
Pero quizá la obra más ambiciosa de Salazar y Torres sea un extenso poema, imitación burlesca de las Soledades, que lleva el siguiente largo título: Discurre el autor en el Teatro de la Vida humana, desde que amanece hasta que anochece, por las quatro Estaciones del dia, no olvidando la fiera ingratitud de su amada Marica, a quien ofrece este Tratado (págs. 67-ro4). Se compone de I2I 7 versos distribuidos en cuatro silvas $(226,307,266$ y 458 versos, respectivamente), que Salazar llama Estaciones y subtitula de "Discursos" ${ }^{1}$. En realidad, no todo pertenece a Salazar; él escribió las tres primeras Estaciones y $10 \mathrm{~s} 27$ primeros versos de la cuarta; el resto se debe, como se indica en nota impresa al margen del texto, al siempre solícito Vera Tassis ${ }^{2}$.

E1 poema de Salazar, al acecho del chiste y la ingeniosidad festiva, no carece de cierta gracia chocarrera, no del todo ajena a los gustos de Góngora, pero relacionada también con algún aspecto de Quevedo y, más próximo aún, con Jerónimo de Cáncer y Velasco ${ }^{3}$. Maneja Salazar,

1 Un poeta portugués, fiel imitador de Góngora, me refiero a Antonio da Fonseca Soares, había ya compuesto en serio otro poema dividido igualmente en cuatro "Estaciones", correspondientes a las cuatro partes del día, en el cual dos enamorados lamentaban en densos soliloquios sus respectivos desengaños amorosos. Poco hay de común entre los dos poemas - el de Fonseca, inédito, debe ser de entre $165^{\circ}$ y 1656 - pero no dejan de ofrecer cierto parentesco, procedente, sin duda, de la misma fuente: Góngora. Vid. J. AREs MonTEs, Góngora y la poesia portuguesa del siglo XVII. Madrid, 1956, pág. 403 y ss.

2 "Aquí cessó el Autor, y por llenar las Estaciones prosigue el que saca a luz sus obras», Cythara, I, pág. 92.

3 No es éste el único caso, aquí justificado por el carácter burlesco del poema, en que Salazar y Torres se dejó deslizar por la fácil pendiente del chiste, no siempre de buena ley ni de buen gusto; pero en esto, como en el resto, no hacía más que seguir la corriente de su época. En el Canto anebeo citado más arriba, en el pasaje en que se canta la belleza de Cintia, el poeta no resiste a la tentación y dice:

Los humos de la azucena, que has imitado presumo en tus matices, porque en tu beldad serena ya se ha subido el humo a las narices. (Cythara, I, pág. 2o.)

Y en un romance dedicado al marqués de la Fuente, de vuelta de una embajada en Francia:

En fin, señor, yo sabiendo que ha llegado V. Excelencia libre ya de un mal francés, sin azogue y sin dieta... (Pág. 123.) 
con habilidad burlesca, el mismo lenguaje y los mismos recursos estilísticos que utiliza en serio en otras composiciones. Se burla asimismo con donaire, a veces con un poco de desgarro, de algunos de los temas cultivados con unción por la poesía barroca, bromeando con imágenes consagradas por los poetas de la ápoca; pero con un limpio espíritu jocoso, sin pretender hacer critica ni cargar de segundas intenciones sus bromas.

La Estación Primera, dedicada a la Aurora, comienza con una descripción del amanecer, cuyos primeros versos anuncian ya lo que va a ser el tono general del poema:

El Alva hermosa y fría, que bien puede ser fria y ser hermosa, como muger casera y hazendosa, con la primera luz del claro día se levantó, aliñando paralelos, barriendo nubes y fregando Cielos. Salia con las crenchas destrençadas, el jaque descompuesto y echada por los ombros la basquiña; sólo un zarcillo puesto, que, porque el Sol, que viene, no la riña y regarle el salón del Mundo presto, dexó prendido el otro en la almohada;

E1 Alba, apresurada y con una regadera en la mano, riega plantas y rocía flores, matizando los regazos de las montañas y peinando de sombras las malezas; después, «bordó de plata las espumas canas/de los undosos ríosm. Comienza de nuevo el despertar de la vida: cantan los pájaros, se retira la Luna y

El Alva, pues, mirando ya vacio uno y otro Orizonte y que Pyrois y Etonte, dos cavallos del Sol Napolitanos, venian abollando con las manos del sossegado Mar la tersa plata, cada qual con su manta de escarlata, boló con alas de jazmín y rosa a dorar otros valles y otras cumbres, siguiendo de la noche tenebrosa las apagadas lumbres, por aquellos senderos que le iban enseñando los luzeros. 
El poeta también se despierta, salta de la cama, se viste y sale al prado, inquieto, turbado, "diziendo mil amantes desatinos, / que no dixo más tierno Garcilaso». En un soliloquio aflictivo se dirige a su amada, ausente y zahareña, preguntándole la razón de su desprecio y poniéndole como ejemplos muy de tener en cuenta los de damas famosas enamoradas de no menos famosos caballeros. "¿Dulcinea no amaba a Don Quixote?", pregunta: y surgen así las sombras de Belerma y la reina Ginebra y Angélica, Venus, Pasifae, Semiramis. Porque, si lo desdeña, podrá ser una nueva Aretusa "mudada en fuente presurosa", o Anaxarte, convertida en roca. ¡Ah, quizá toda la culpa sea del Amor, ese hijo de Venus «y, en fin, hijo de putan, que no quebranta la fortaleza de Mariquilla!

E1 Sol, alto, interrumpe las lamentaciones del poeta y pone punto a la Estación Primera:

Aquí llegava, quando

vi que, dándome el Sol en la mollera, el discurso se me iba calentando, pues ya Febo mediava su carrera, a quien llamó Cenit la Astrología y los doctos llamamos Mediodía.

Al mediodía corresponde, en efecto, la Estación Segunda, cuyo primer verso parece iniciar una perifrasis zodiacal del tipo «Era del año la estación floridan, para derivar por otro camino, con una pirueta repetida más veces en las Estaciones:

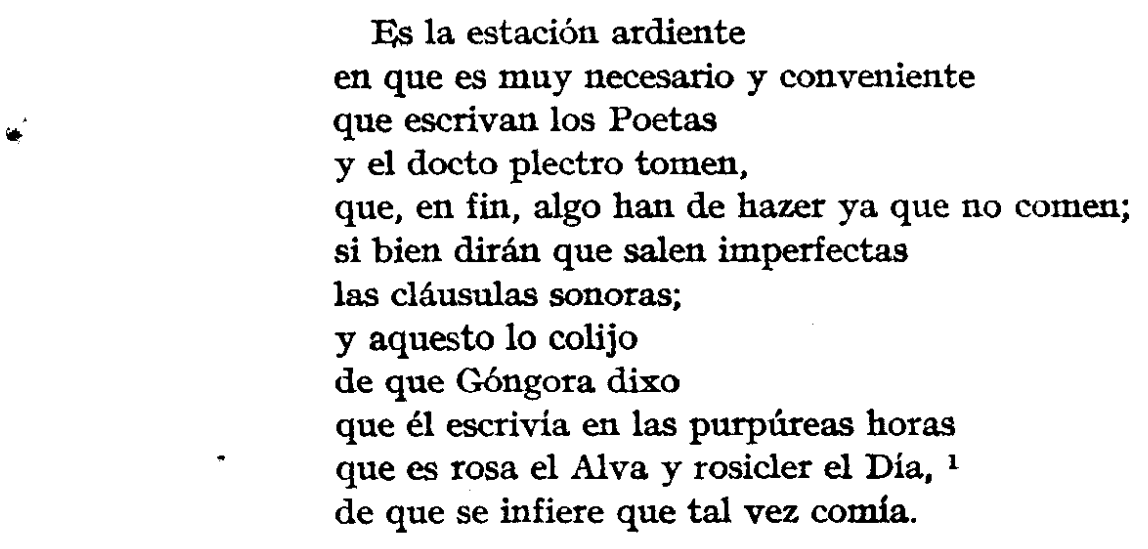

En consonancia con la hora del día cambia el escenario: los segadores se recogen a la sombra de los árboles, el silencio se hace en los bosques, el pescador de caña espera paciente en la orilla a ver si el pez pica:

1 Polifemo, vv. 3-4. 
¡O gana de comer, a lo que mueves!

Que quando al triste el Sol le está abrasando, subiendo está y baxando sus plomos graves y sus corchos leves. ¡Qué lindo verso a Góngora le he hurtado! 1 Por Dios, que yo pesqué y él no ha pescado; bueno es coger aquello que se acuerda.

Cantan las chicharras; en el hogar voltean los asadores; el pretendiente huye del.solazo de las plazuelas buscando el frescor de los rincones. Todos sestean ya; sólo el poeta, desalentado por la esquivez de su dama, no tiene sosiego. La dama, ¡ay!, a quien entrevemos «soplando el caldo, porque está caliente", para sorberlo rumorosamente a continuación. Su enamorado nos ofrece de ella una delicada imagen en la que no faltan las metáforas de todos los ideales retratos femeninos cristalizados por la poesía de la época (cristales, clavel, jazmín, rosa, perlas, corales, nieves, rubí...), que el contraste con la realidad va destruyendo implacablemente:

Apenas toca el pan con los cristales, quando, aunque sea moreno, de mijo u de centeno, se hazen las rebanadas candeales; y si un dedo le toca, amassado con leche va a la boca; mas como ni cuidado ni amor siente, come bonicamente, tanto, que el plato menos regalado, no solo queda limpio, mas fregado. $\mathrm{Si}$ es dulce lo que come, es tan discreta, que jamás se limpió en la servilleta; luego los dedos al clavel aplica, como la que se pica con alfiler o aguja y la sangre se chupa sin ser bruja; jó Amor, se te quitaran mil pesares si la vieras lamerse los pulgares! Compuesto hechizo de jazmin y rosa, que es el último estremo de golosa; con perlas masca y con corales bebe, pues sus dientes son nieve y sus labios son ascuas; y ella está más contenta que mil Pascuas de saber que en su risa, en fuego o en nieve, es la prisión precisa.

1 Se refiere al famoso v. 40 del Polifemo, kgimiendo tristes y volando gravess. 
Después ve

que ha cogido el pallillo

y al partido rubi le ha trasladado.

Marica, en fin, va a descansar la comida y mientras duerme (nuevo contraste entre idealismo poético y realidad burda):

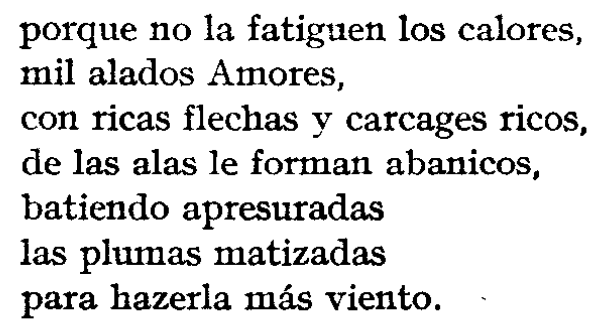

Pero una mosca le pica en la garganta y

Ved con la gracia que la picadura de la mosca se rasca con blandura, con las uñas piadosas y crueles, aliviando lo mismo que maltrata, y en campañas de plata, arando cinco sulcos de claveles.

Ahora el poeta, después de estos efectos cómicos, va a burlarse, joh sentimiento del desengaño!, de tema tan caro a la poesía barroca como es el de las ruinas, con sus moralidades sobre la brevedad de la vida y la belleza fungible, eterna sólo a través de los versos del poeta:

Esto dezía, quando ya abrasado, por huir el perjuyzio del Sol, me fui azia unos paredones que el tiempo su enemigo ha devorado, y el que antes era Dórico edificio, oy hasta los cimientos son terrones: jó qué de admiraciones causas, veloz edad, en los que huellas! pues fábrica, a quien fueron las Estrellas, con vagos tornasoles, sus trémulos faroles, ahora sustenta, de su mal testigos, en vez de chapiteles, cabrahigos.

$\mathrm{V}$ los que componian artesones, molduras y dibuxos roxos escaramujos y zarças guarnecian, 
siendo los quartos baxos,

que antes pulieron láminas y espejos, camarin de vencejos

y alcoba aun no capaz para los grajos;

el salón que adornavan los matizes

del Cayro en las alfombras y terlizes

alhaja tal tenfa,

que aun poniendo la mano en las narizes

ni olerle ni mirarle consentía:

por las rotas rendijas,

entre matas espesas,

entran salamanquesas

y salen lagartijas:

ni aun la ruina quedó del edificio.

¿Buen verso de Lucano!

que yo no he de morir, que soy Christiano.

En fin, perdiera el juicio,

si acaso le tuviera,

mirando quán ligera

corre la edad, y el tiempo, que presume

de cojo y rengo, todo lo consume.

$\mathrm{Y}$ hablando con mi afecto le dezia;

iAy dulcíssimo bien del alma mía!

si una torre que al Cielo se avezina

resolvieron los años en ruina;

con ser de cal y canto su estructura,

siendo de mantequilla tu hermosura,

de colegir se dexa

que al fin, al fin, has de llegar a vieja.

¿Quién ignoró el poder de las edades?

No duran peñas, ¿durarán beldades?

Fenece la belleza,

pero si acaba, en el pincel empieza

y el buril peregrino;

ya retratada en mármol o ya en lino;

pero también se acaba la hermosura

en estatua o pintura,

porque una, al fin, se borra, otra se quiebra;

la beldad sólo dura que celebra

el Ingenio, que él sólo se ha eximido

de las leyes del tiempo y del olvido;

con que en mis rudos versos celebrada

tu beldad durará privilegiada,

sin que olvido ni tiempo la consuma,

$y$, en fin, eterna vivirá en mi pluma.

Hermosuras perfectas,

mirad lo que debéis a los Poetas,

$y$ advertid que es muy gran vellaqueria

embiarlos noramala cada día. 
La Estación Tercera, dedicada a la tarde, liga en sentido narrativo con el episodio anterior:

Mas dexando a una parte digressiones, al tiempo que dexé los paredones, mayor sombra caia de los cercanos montes a los valles.

iO Musa, que te halles

al punto tan a mano

la hermosa imitación del Mantuano en la Egloga primera! 1.

Ya el Sol apresurava su carrera en su coche dorado, todo desabrochado, iimpiando con un lienço los sudores,

Desta suerte camina, roxo como un granate, azia donde se cria el chocolate o aquellos ingredientes, por lo menos, que componen tan dulce golosina.

Nueva burla. Le toca ahora la vez al tema de la caza: las frías madrugadas, las fatigadas selvas, los tristes galgos y los fracasados cazadores cruzan, en una visión rápida y certera dentro de su comicidad, por los versos de Salazar y Torres:

y al ver los Cielos claros y serenos
el calor se aminora,
y la purpúrea tarde boladora,
moça rolliza, mas de buena traça
con alas de cristal iva llamando
a los que, fatigando
el bosque, siguen la ligera caza,
trepando riscos y venciendo cerros,
que después de tratarse como perros,
aviendo madrugado,
rendido y despeado,
arañado de cardos y zarçales
y en los duros xarales
el vestido hecho trapos
dize que no ay mayor divertimiento,
y viene muy contento
de que heridos se fueron dos gazapos
y dexaron las plumas las perdizes
................................

1 Alude a VIrgrio, Egloga I, 83, maioresque cadunt altis de montibus umbrae». 
Pero no es ahora el momento de celebrar la sabrosa, pero humilde caza leporina, ni la peligrosa montería:

Pero aora mi ingenio no celebre al cazador que corre tras la liebre fatigando al rocín y al triste galgo,

no pintaré en la caza los excessos del javalí acosado de sabuessos,

ni por quitarle el robo, descrivo el cazador que sigue al lobo,

Tampoco a celebrar el tiempo obliga al cazador mañero, con la astucia vulgat de red o liga,

No, ahora hay que cantar el noble deporte de la cetrería, que también cantó bellamente Góngora en su Soledad Segunda, tan resonante en este pasaje de la Estación Tercera. Quizá por esto Salazar se muestra respetuoso, se deja llevar por el tema, seriamente, hasta que de pronto se da cuenta que ése no es el camino y, con una cabriola, nos trae de nuevo a la urealidad» del poema:

\footnotetext{
Mas con sonora lyra, Musa mía, de la Real Cetrería haz generoso alarde, pues que la ves pintada con la tarde: Ya el buho prevenido en el llano tenía el alconero, y el páxaro agorero ofrecia a las cuervas por despojos el oro de sus ojos, que este metal de suerte las inclina, que a su esplendor se arrojan presurosas, tenazes y protervas y ay en el Mundo infinidad de cuervas con esta propiedad de codiciosas; pero apenas al riesgo se avecina la negra vanda y al peligro vuela, quando desenlazando la pihuela y quitando al alcón el capirote a la que ve zorrera la da un bote; pero ella de sus uñas se resvala y como flecha por el ayre sube, mas el grifanio alcón el viento escala
} 
y alcándara formando de una nube, ya remontando, ya cogiendo puntas, tanto remonta el altanero buelo, que aunque la cuerva se subiesse al Cielo, allá fuera a buscarla con deseo de herirla y alcançarla haziendo en las Estrellas escarceos, que siempre buelan tanto los deseos; pero ella va bolando y él siguiendo, y como en uno y otro el subir crece, por Dios que ya ninguno no parece y que los cazadores van corriendo, diziendo: Tó, tó, tó. Bien hemos quedado, todos se han ido y esto se ha acabado.

Sí, se ha acabado la caza, para penetrar en el mundo pastoril, en el que no se topan «los pastores de Lope/en su Arcadia fingida», ni los dulces Nemorosos garcilasianos, sino la realidad de unos brutos cabreros y una sucia pastora:

Demás de que me llaman los pastores cantando sus amores, no como allá los pinta Garcilaso, que los hace cantar a cada paso mejor que Ministriles; sus cabras conduciendo a sus rediles vienen, porque no dora ya Febo la campaña; pero de la cabaña salia a recibirles la pastora; y que no era la Nimpha, certifico, nieve el pecho y armiños el pellico, pues sólo era su aliño de sayal un corpiño, y las manos, que no eran de manteca, los mechones pelavan de una rueca; de buri 1 el manteo y hecho andrajos, con dos dedos de costra en los zancajos.

A los nombres de Garcilaso y Lope se une un nuevo toque virgiliano $^{1}$, y hasta, de pasada, una nota del paisaje americano:

Ya cessavan del todo las tareas del que avienta y que trilla, y es porque ven que en la cercana Villa humeavan las altas chimeneas;

1 Sin duda, "en la cercana Villa / humeavan las altas chimeneas» es una reminiscencia de "et iam summa procul villarum culmina fumant», Egl. I, 82. 
el sabio agricultor dexó el arado

con que avía arañado

de la tierra la faz en el barbecho

y reducía a su pagizo lecho

los bueyes que, con passos de pavana,

con tarda huella pisan la savana ${ }^{1}$

aun no de la coyunda divididos,

si bien del dulce son van divertidos

que el juego forma en el sonante hierro

a quien la erudición llama cencerro.

En medio de tanta belleza evocadora, el poeta recuerda de nuevo las gracias y encantos de su Mariquilla y lamenta otra vez su inquebrantable actitud desdeñosa, para terminar con la Estación:

Mas ya se puso el Sol en el Poniente, siendo urna un monte a su esplendor luziente:

ya en luto el Mundo la tiniebla espesa

y mi dolor no cessa:

¡O dura, infatigable suerte impía,

pues no muere mi pena y muere el día!

La Estación Quarta pertenece a la noche, cuyas sombras debieron impedir a Salazar llegar hasta una nueva aurora, porque no remontó la silva más allá del verso veintisiete:

Estavan ya los claros Orizontes, que es donde sólo nuestra vista llega

y por donde parece que se pega

el Cielo con los montes, con luz escasa, al caducar el día, como vela que ardía con tibia luz, que, porque alumbra poco, quieren limpiarla el moco

y en lugar de atizarla, suelen despavilarla, apretando de modo que queda obscuro todo,

1 La dependencia del Polifemo, vv. 70-72, es clara:

...con paso lento

los bueyes a su albergue reducia, pisando la dudosa luz del dia.

Sobre 'savana', COROMINAS, Diccionario critico, dice que la grafia con $s$ inicial no aparece hasta el siglo XVIII, escribiéndiose 'çavana' durante los siglos XVI y $\mathbf{X}$ vIr. El ejemplo de Salazar es un precedente curioso. 


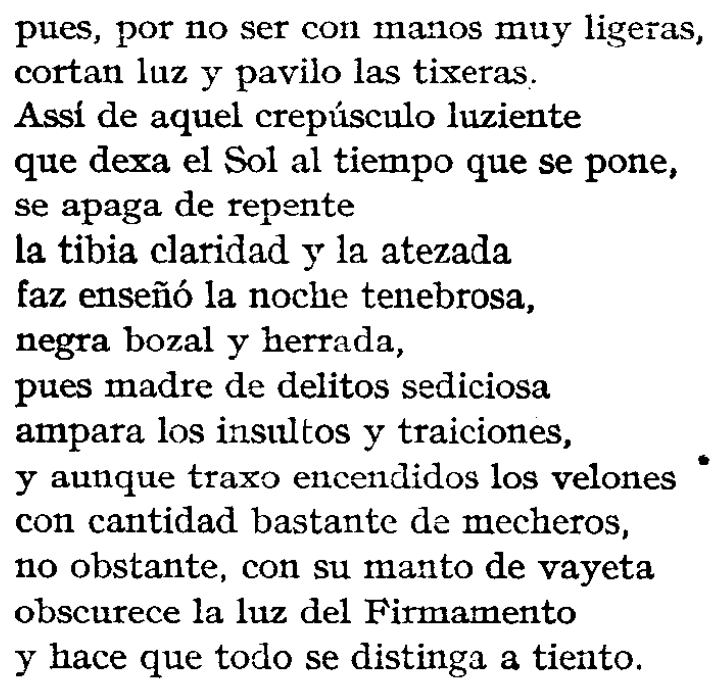

En la continuación de Vera Tassis, desmedidamente extensa en comparación con las Estaciones originales, no encontramos la desgarrada gracia de Salazar ni el ágil desarrollo de sus divagaciones, debido quizá esto último a la preferencia que muestra Vera por el endecasílabo. Hay aquí un largo y lamentoso soliloquio del poeta, que ve a lo lejos desnudarse a Marica y bien quisiera ayudarla; pero ni aun el placer de la vista logra, porque una cortina corrida o un apagado candil le arrebatan la visión de la moza. Con las débiles, lejanas luces de una nueva aurora termina definitivamente el poema ${ }^{1}$.

Teatro.

Como autor dramático, Salazar y Torres se muestra decidido discípulo de Calderón, al menos en el aparato externo y en la preferencia por los asuntos mitológicos, alguno de los cuales ya había sido llevado a la escena por el maestro.

1 De la masa de versos añadidos por Vera TASSIS, recordemos sólo los siguientes por lo que tienen de resonancia gongorina:

En fin, como dezia, en repetidos

lamentos resonava con gemidos

la infame turba de nocturnas aves, gimiendo tristes. Tengan, que yo temo que aquí he de trasladar el Polifemo, y Góngora fue un hombre tan honrado que dél nadie creerá que me lo ha hurtado: esto llaman los Doctos en la Historia escrivir de memoria el que tiene infeliz entendimiento. (Pág. 94.) 
También Salazar fue proveedor de comedias para fiestas cortesanas en los cumpleaños de Carlos II o de doña Mariana de Austria, o para diversión de los duques de Alburquerque, aunque algunas de sus piezas, por lo menos las de asunto no mitológico, fueron representadas también públicamente.

Es éste un teatro de tramoyas y apariencias, con predominio de elementos líricos, no sólo poéticos, sino también cantables, por lo que pueden calificarse de zarzuelas la mayor parte de sus piezas, menores y mayores, pues en ellas abundan los coros, arias y bailables. Todo es de una extrema artificiosidad, con innegables aciertos de finura, gracia y ritmo, porque Salazar no olvida nunca que sabe hacer versos, pero sin profundidad en los conflictos ni fuerza en los personajes, entre los que no se encuentra un solo carácter: son simples tipos o, mejor, bellas figuras decorativas descendidas de sus pedestales olímpicos para cantar sus ansias amorosas o recitar, en largas relaciones cargadas de rutilantes imágenes culteranas, sus trabajos y vicisitudes. Comedias, en fin, de gran espectálo, en las que la vista se recrea en suntuosos desfiles y apariciones y el oído en la música del verso y en la otra.

En la Primera Parte de la Cythara de Apolo se publicó el teatro menor de Salazar: dos loas y cinco bailes. Las loas fueron escritas para comedias ajenas: una para la comedia Eurídice y Orfeo, posiblemente la de Antonio de Solís, y otra para Dar tiempo al tiempo, de Calderón. Entre los bailes destacan el de Los Elementos y el de Amor y Zelos, los otros - Amor y Desdén, Hermosura y Discreción y Juego del Hombre- son demasiado anodinos.

La Segunda Parte de la Cythara, como queda indicado más arriba, comprende nueve comedias, ocho con sus respectivas loas. Una pieza religiosa, La mejor flor de Sicilia, Santa Rosolea (con loa), comedia de santos, cuya protagonista, tras luchar contra las asechanzas del demonio, abandona, con coros de ángeles como fondo, pompas y vanidades por una vida eterna. Comedias de enredo (iqué pocas no lo son en nuestro teatro del siglo Xvir!): Elegir el enemigo (con loa), cuya acción -entrevistas nocturnas, equivocaciones, amores encontrados y final convencional de bodas y abrazos- tiene lugar en un imaginario reino de Creta, y El encanto es la hermosura y el hechizo sin hechizo (con loa), conocida también por La Segunda Celestina, con cuyo título se representaba todavía en Madrid a comienzos del siglo xIx. Esta ágil comedia de carácter costumbrista, muy alabada por Menéndez Pelayo ${ }^{1}$, chenta entre sus personajes una curiosa versión de Celestina, si bien la "componedora"

1 Origenes de la novela. III. Ed. Nac., Santander, 1943, págs. 451-452. 
de Salazar y Torres, edulcorada para «el cumplimiento de años de la Reyna nuestra Señora", carece en todo momento de la tremenda fuerza sugestiva de la creación de Rojas ${ }^{1}$. Casi todo el tercer acto es de Vera Tassis.

Otra pieza, El mérito es la corona y encantos de mar y amor (con loa), es comedia fantástica, emparentada con El castillo de Lindabridis, de Calderón. El resto son fantasías mitológicas que hubiera podido firmar sin mayor reparo el mismísimo autor de La vida es sueño: El amor más desgraciado, Zéfalo y Pocris (con 1oa) 2; También se ama en el abismo

1 Asi la retrata un personaje en la primera jornada de la comedia:

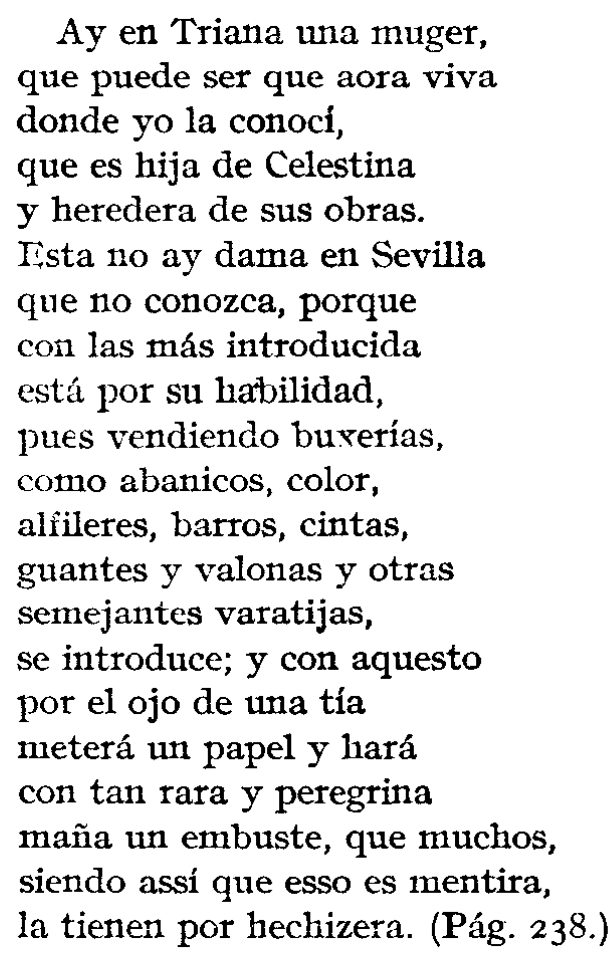

2 El parentesco con Calderón, que ya había tratado este tema en Celos, aun del aire, matan, nos lo muestran, juntamente con el de Góngora, los siguientes versos puestos en boca de Céfalo:

Por la luziente, por la vaga Essfera, precipitava el Alva su carrera, ahuyentando con cada movimiento quanta sombra empañava el Firmamento, dexando con dudosos resplandores muertos los Astros ya, vivas las flores, pues al equivocar sus luzes bellas, pintava flores y borrava Estrellas. 
(con loa); Los Juegos Olimpicos (con loa); Thetis y Peleo (con loa) ${ }^{\mathbf{1}}, \mathbf{y}$ Triunfo y venganza de amor, con el mismo asunto de El Laurel de Apolo, de Calderón.

Fuera de la Cythara quedan aún dos comedias: Olvidar por quever bien y Más triunfa el Amor rendido. Aunque La Barrera ha clasificado la primera como auto sacramental, quizá porque en las tres ediciones sueltas en que se conserva (Madrid, Valladolid y Salamanca, las tres $\sin$ año) se la llama "Auto del Nacimiento del Hijo de Dios》 intitulado Olvidar por querer bien, se trata, en realidad, de una comedia en tres jornadas y

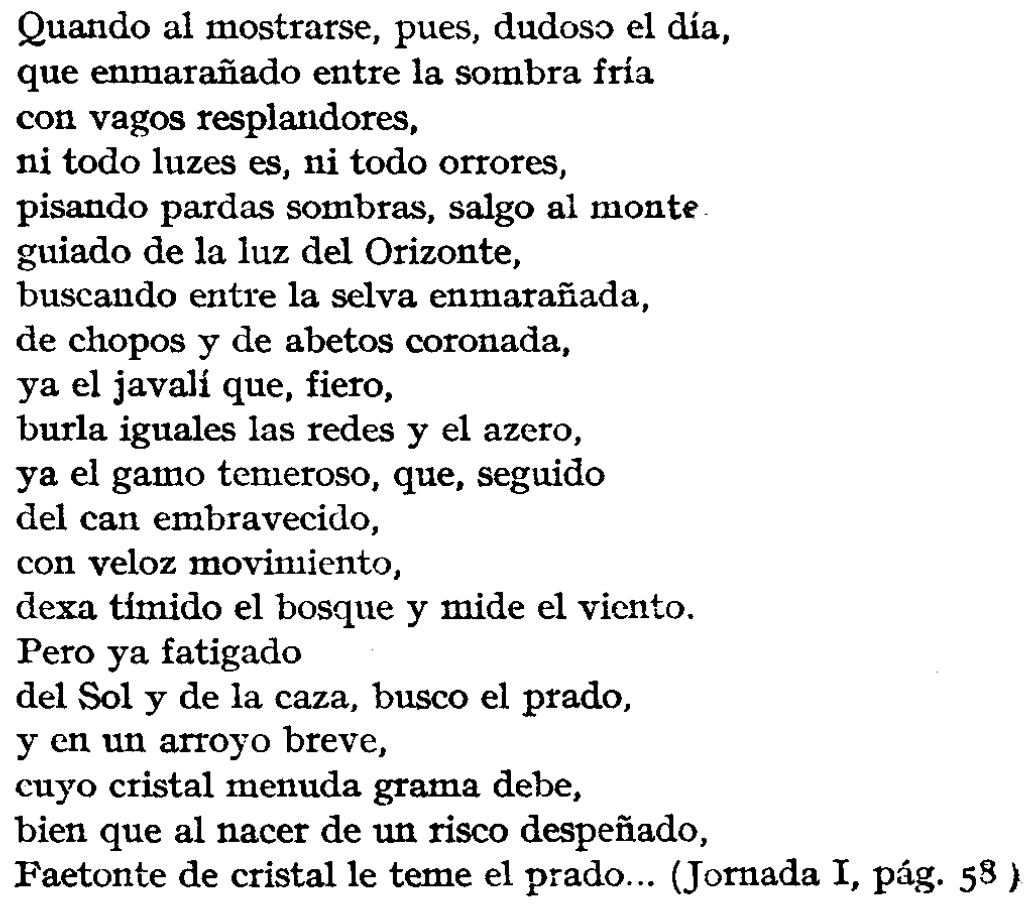

1 Aquí se encuentra, jornada primera, pág. 340, este bello soneto:

Suelto el cabello que prisión ignora, sobre azucenas dilató espacioso, ya el prado inunda en ondas proceloso, ya con hebras de luz los ayres dora.

El breve nácar que al Abril colora, ámbar concede al prado venturoso, y en lo demás del rostro milagroso, venció a despierto Sol dormida Aurora.

Aún faltándole el Alma a su cuydado, en lo sereno de su dulce calma ninguna libertad se vio segura.

Deidad ingrata, dixe enamorado, si en tu hermosura está de más el alma, ¿cómo el alma será de tu hermosura? 
con todas las características de las comedias, en este caso religiosa por su asunto, pero sin las alegorías propias de los autos sacramentales y con un desarrollo más amplio del que suelen tener estas piezas. Personaje importante es Lucifer, que hace todo lo posible por labrar la desgracia de la santa pareja, despertando los celos de San José, y trata de malquistar a Laura y Silvio, pareja de enamorados que representa el lado profano de la comedia. Naturalmente, el demonio sale derrotado y, al final, se descubre el Portal, adonde acuden todos a adorar al recién nacido.

Más triunfa el Amor rendido, que se publicó como "gran comedia» de tres ingenios (Sevilla, s. a.), es sólo de Salazar y Torres, que escribió el primer acto, y de Vera Tassis, a quien se deben los otros dos. Esta comedia mitológica, o, si se prefiere, zarzuela, ya que en ella abunda la música y el canto, es posiblemente la que, con el título de Minos y Britomartis, anuncia Vera en la Advertencia a la Primera Parte de la Cythara: "Aun más de una Jornada de la Comedia de Minos y Britomartis", pues estos dos nombres - Briomarte en Más trinnfa el amor rendido - lo son de dos personajes principalísimos de esta obra, que también hubiera podido titularse Endimión y Diana 1 .

Conclusión.

Creo que, después de leídas estas páginas, podrá admitirse sin objeciones la íntima relación existente entre la obra de Salazar y Torres y la de Góngora, $y_{6}$ se reconocerá también su legítimo derecho a ocupar un lugar más destacado, y no sólo conı autor dramático dependiente de Calderón, en las historias de la Literatura española, al lado de los Bocángeles, y Villamedianas de turno.

Agustín de Salazar y Torres es un poeta hábil, plástico, con un fino sentido del ritmo, ampliamente demostrado en sus composiciones líricas y en gran número de pasajes de las dramáticas; proclive a la pompa del color, a los cultismos y a las imágenes y metáforas de todo género; no le falta donaire cuando hace versos de burlas: sólo le falta en todo momento, y de esto no hay quien le salve, verdad, sinceridad, calor humano, algo que no sea un superficial juego de recursos expresivos que no deja en el espíritu del lector ninguna huella.

\section{José AREs MONTES.}

1 LA BARRerA, Catálogo del Teatro Antiguo Español, confunde Triunfo y venganza de amor con Más triunfa el Amor rendido, haciendo de ambas una sola comedia. 